\title{
RANCANG BANGUN APLIKASI TRACKING DELIVERY PADA CV PETRO ASIA JAYA UTAMA BERBASIS WEB
}

\author{
Rosina Koto Humeon ${ }^{*}$, Rahmat Gunawan ${ }^{2}$ \\ ${ }^{1}$ Rosina Koto Humeon: ${ }^{1}$ STMIK Rosma \\ ${ }^{2}$ Rahmat Gunawan: ${ }^{2}$ STMIK Rosma \\ Email: rosyhumoen@gmail.com,rahmat@rosma.ac.id
}

\begin{abstract}
The system used at CV Petroasia Jaya Utama currently tends to still manually use books and agendas, so that problems often arise such as recording errors in processing data on delivery and recapitulating consumer data which takes a long time so that it is less supportive, less fast and flexible in terms of processing. present information. The application used to process data is also still simple, namely Microsoft Office Word and Excel. Consumers and marketing officers must communicate with each other to ensure information about the goods sent, such as the status of the delivery of the goods, whether the goods have arrived or not. In this study, the aim of this research is to analyze system requirements by designing a system using UML (unified modeling language) and the framework used in the analysis process is the PIECES (Performance, Information, Economic, Control, Efficiency, and Service) method. This system includes the process of ordering goods, shipping and monitoring the status of delivery of goods, therefore a web-based tracking system is needed. This system is designed with PHP programming language and MySQL as database. The conclusion of this research is that the web-based delivery tracking system is expected to make it easier for consumers and employees of CV Petroasia Jaya Utama in managing tracking data ordering data, as well as providing information to consumers in the latest and appropriate circumstances.
\end{abstract}

Keywords: Tracking Delivery, PIECES, Web, Php,MySQL

Abstrak

Sistem yang digunakan di CV Petroasia Jaya Utama saat ini cenderung masih secara manual menggunakan buku dan agenda, sehingga sering timbul permasalahan yang terjadi seperti kesalahan pencatatan dalam pengolahan data pengiriman dan rekapitulasi data konsumen yang membutuhkan waktu cukup lama sehingga kurang mendukung, kurang cepat dan fleksibel dalam menyajikan informasi. Aplikasi yang digunakan untuk mengolah data juga masih sederhana yaitu microsoft office word dan excel dan Konsumen dan petugas marketing harus saling berhubungan untuk memastikan informasi mengenai barang yang dikirim seperti status pengiriman barang apakah barang tersebut sudah sampai atau belum. Pada penelitian penelitian ini bertujuan untuk melakukan analisis kebutuhan sistem dengan merancang sebuah sistem menggunakan UML (unified modeling language) dan kerangka yang digunakan dalam proses analisis adalah metode PIECES (Performance, Information, Economic, Control, Efficiency, dan Service). Sistem ini meliputi proses pemesanan barang, pengiriman dan pemantaun status pengiriman barang, oleh karena itu dibutuhkan suatu sistem tracking berbasis web. Sistem ini dirancang dengan bahasa pemograman php dan MySQL sebagai database. Kesimpulan dari penelitian ini, yaitu dengan adanya sistem tracking delivery berbasis web ini diharapkan dapat mempermudah konsumen dan karyawan CV Petroasia Jaya Utama dalam mengelola data pemesanan data tracking, serta dapat memberikan informasi kepada konsumen secara terbaru dan sesuai dengan keadaan.

Kata Kunci: Tracking Delivery, PIECES, Web, Php, MySQL

\footnotetext{
Article History:

Accepted 3, November, 2020

Corresponding Author:

Nama Penulis, Rahmat Gunawan

Departemen, STMIK Rosma

Instansi, STMIK Rosma

Alamat. Jl. Kertabumi No.62 Karawang Barat 41311 Karawang, Jawa Barat.

Email Penulis.rahmat@rosma.ac.id
}

Jurnal Interkom: Jurnal Publikasi Ilmiah Bidang Teknologi Informasi dan Komunikasi

Volume 15 Nomor 03 Bulan Oktober - Tahun 2020 


\section{Pendahuluan}

Dalam perkembangan teknologi dari hari ke hari semakin berkembang, dimana kebutuhan akan tenaga-tenaga profesional akan semakin diperlukan oleh perusahaan besar maupun perusahaan kecil. Kehidupan manusia tidak lepas dari penggunaan internet, dikarenakan akses internet era sekarang penggunaannya cukup mudah. Dalam penggunaan internet, manusia akan memperoleh informasi dari website informasi yang beragam. Selain memperoleh informasi yang beragam, manusia dapat mengakses website setiap waktu. Era sekarang kebutuhan akan informasi yang cepat dan akurat sangat dibutuhkan. Salah satu kebutuhan informasi yaitu informasi pemesanan dan pengiriman barang berbasis web. Pelanggan atau perusahaan pengiriman barang memerlukan suatu aplikasi pelacakan pengiriman barang menggunakan web yang dapat menghasilkan informasi pengiriman barang yang cepat dan akurat. Dalam bidang pengiriman barang sebaiknya sistem dapat mengakomodasi kebutuhan tracking atau pelacakan terhadap barang yang sudah dikirimkan.

CV Petroasia Jaya Utama merupakan salah satu perusahaan distibutor minyak pelumas yang berlokasi di Kabupaten Karawang. Perusahaan ini bergerak dalam bidang perdagangan minyak pelumas. Saat ini CV Petroasia Jaya Utama sedang berupaya untuk meningkatkan layanan serta standar kualitas dari berbagai sisi antara lain sisi pemanfaatan teknologi informasi.

Sistem yang berjalan pada $\mathrm{CV}$ Petroasia Jaya Utama saat ini memiliki permasalahan - permasalahan diantaranya sistem pemesaan dan pengiriman barang saat ini cenderung masih secara manual menggunakan buku dan agenda, sehingga sering timbul permasalahan yang terjadi seperti kesalahan pencatatan dalam pengolahan data pengiriman dan rekapitulasi data konsumen yang membutuhkan waktu cukup lama sehingga kurang mendukung, kurang cepat dan fleksibel dalam menyajikan informasi. Aplikasi yang digunakan untuk mengolah data juga masih sederhana yaitu microsoft office word dan excel dan Konsumen dan petugas marketing harus saling berhubungan untuk memastikan informasi mengenai barang yang dikirim seperti status pengiriman barang apakah barang tersebut sudah sampai atau belum hal ini tentunya akan memakan waktu dan tenaga. Situasi ini berdampak pada kurang lengkap dan akuratnya laporan pemesanan dan pengiriman barang kepada pihak manajemen dan konsumen sehingga sulit dalam mengambil keputusan yang tepat.

Berdasarkan uraian permasalahan tersebut, penulis mencoba memberikan solusi untuk membuat sistem berbasis web dalam pemesanan dan pengiriman barang, aplikasi web yang dibuat memberikan informasi mengenai pemesanan barang serta pemantauan status pengiriman barang dan memberikan informasi lain yang berguna bagi konsumen.

Aplikasi ini dapat memperkecil kendala hilangnya barang, dan barang yang dikirimkan akan sampai di tempat tujuan sesuai dengan rencana awal pengiriman, serta penelitian ini bertujuan untuk melakukan analisis kebutuhan sistem dengan merancang sebuah sistem menggunakan UML (unified modeling language) dan kerangka yang digunakan dalam proses analisis adalah metode PIECES (Performance, Information, Economic, Control, Efficiency, dan Service).

\section{Tinjauan Pustaka}

Beberapa teori atau definisi yang berhubungan dengan penelitian ini diuraikan sebagai berikut :

\section{Rancang Bangun}


Menurut Pressman (2009) "perancangan atau rancang merupakan serangkaian prosedur untuk menterjemahkan hasil analisa dan sebuah sistem ke dalam bahasa pemrograman untuk mendeskripsikan dengan detail bagaimana komponenkomponen sistem di implementasikan."

Menurut Pressman (2009) "pengertian pembangunan atau bangun sistem adalah kegiatan menciptakan sistem baru maupun mengganti atau memperbaiki sistem yang telah ada secara keseluruhan. Jadi dapat disimpulkan bahwa Rancang Bangun adalah penggambaran, perencanaan, dan pembuatan sketsa atau pengaturan dari 78 beberapa elemen yang terpisah kedalam suatu kesatuan yang utuh dan berfungsi. Dengan demikian pengertian rancang bangun merupakan kegiatan menerjemahkan hasil analisa ke dalam bentuk paket perangkat lunak kemudian menciptakan sistem tersebut atau memperbaiki sistem yang sudah ada."

\section{Aplikasi}

Aplikasi adalah salah satu unit perangkat lunak yang dibuat untuk melayani kebutuhan akan beberapa aktivitas (Supadi,2015:4).

\section{Metode Analisis PIECES}

Metode analisis sistem yang digunakan adalah metode PIECES (Performance, Information, Economic, Control, Efficiency, dan Service). Berikut adalah penjelasan mengenai analisis PIECES menurut Wukil Ragil (2010), adalah metode analisis sebagai dasar untuk memperoleh pokok-pokok permasalahan yang lebih spesifik. (Wukil Ragil, 2010:17) Analisis PIECES (Performance, Information, Economy, control, Eficiency, dan Service) merupakan teknik untuk mengidentifikasi dan memecahkan permasalahan yang terjadi pada sistem informasi. Dari analisis ini akan menghasilkan identifikasi masalah utama dari suatu sistem serta memberikan solusi dari permasalahan tersebut. Analisis PIECES terdiri dari: a. Performance (kinerja)

Performance (kinerja) adalah kemampuan menyelasaikan tugas pelayanan dengan cepat sehingga sasaran atau tujuan segera tercapai. Kinerja diukur dengan jumlah produksi (Troughput) dan waktu tanggap (Respon Time) dari suatu sistem.

b. Information (informasi)

Information (informasi) adalah evaluasi kemampuan sistem informasi dalam menghasilkan nilai atau produk yang bermanfaat untuk menyikapi peluang dalam menangani masalah yang muncul.

c. Economic (biaya)

Economic (biaya) adalah penilaian sistem atas biaya dan keuntungan yang akan didapatkan dari sistem yang diterapkan. Sistem ini akan memberikan penghematan operasional dan keuntungan bagi instansi atau perusahaan. Hal yang diperlukan dalam analisis ini meliputi biaya dan keuntungan.

d. Control (keamanan)

Control (keamanan) adalah sistem keamanan yang digunakan harus dapat mengamankan data dari kerusakan, misalnya dengan membeck up data. Selain itu sistem keamanan juga harus dapat mengamankan dta dari akses yang tidak diizinkan. Analisis ini meliputi pengawasan dan pengendalian.

e. Efficiency (efesiensi)

Efficiency (efesiensi) adalah sumber daya yang ada guna meminimalkan pemborosan. Efesiensi dari sistem yang dikembangkan adalah pemakaian secara maksimal terhadap sumberdaya infrastuktur, dan sumberdaya manusia. Serta efesiensi juga menganalisis keterlambatan pengolahan data yang terjadi.

f. Service (layanan)

Service (layanan) adalah mengkoordinasikan aktifitas dalam 
pelayanan yang ingin dicapai sehingga tujuan dan sasaran pelayanan dapat capai.

\section{Website}

Web Page (halaman web) merupakan halaman khusus dari situs web tertentu yang tersimpan dalam bentuk file. Dalam web page, tersimpan berbagai informasi dan link yang menghubungkan suatu informasi ke informasi lain, baik itu dalam page yang sama ataupun web page lain pada website yang berbeda.

Website merupakan teknik yang paling umum untuk menampilkan informasi di dalam internet. Dapat diakses melalui web browser yang menampilkan web page dari grafik yang ada dan teks sandi HTML atau XML. (Dave Chaffey, 2011:4).

\section{Framework}

Menurut Hakim (2010:3) menjelaskan bahwa, Framework adalah koleksi atau kumpulan potongan-potongan program yang disusun atau diorganisasikan sedemikian rupa, sehingga dapat digunakan untuk membantu membuat aplikasi utuh tanpa harus membuat semua kodenya dari awal.

\section{Framework Laravel}

Menurut Rahmat Awaludin (2014:5) Laravel adalah framework bahasa pemrograman Hypertext Preprocessor (PHP) yang ditujukan untuk pengembangan aplikasi berbasis web dengan menerapkan konsep Model View Controller (MVC). Framework ini dibuat oleh Taylor Otwell dan pertama kali dirilis pada tanggal 9 Juni 2011.

\section{MySQL}

MySQL adalah nama database server. Database server adalah server yang berfungsi untuk menangani database. Database adalah suatu pengorganisasian data dengan tujuan memudahkan penyimpanan dan pengaksesan data. Dengan menggunakan MySQL, kita bisa menyimpan data dan kemudian data bisa diakses dengan cara yang mudah dan cepat. (Abdul Kadir, 2013:15).
Beberapa kelebihan MySQL, dibandingkan dengan sistem basis data sejenis seperti Microsoft SQL Server, Oracle:

a. Kemampuan yang tinggi.

b. Tidak dibutuhkan biaya untuk mendapatkan MySQL.

c. Mudah untuk konfigurasi dan dipelajari.

d. Dapat dijalankan pada beberapa sistem operasi seperti sistem Unix dan Microsoft Windows.

\section{Metode}

Berdasarkan masalah yang sedang diteliti dan tujuan yang hendak dicapai pada penelitian ini maka ditentukan tahapantahapan penelitian yang secara garis besar dapat dilihat pada gambar 1 .

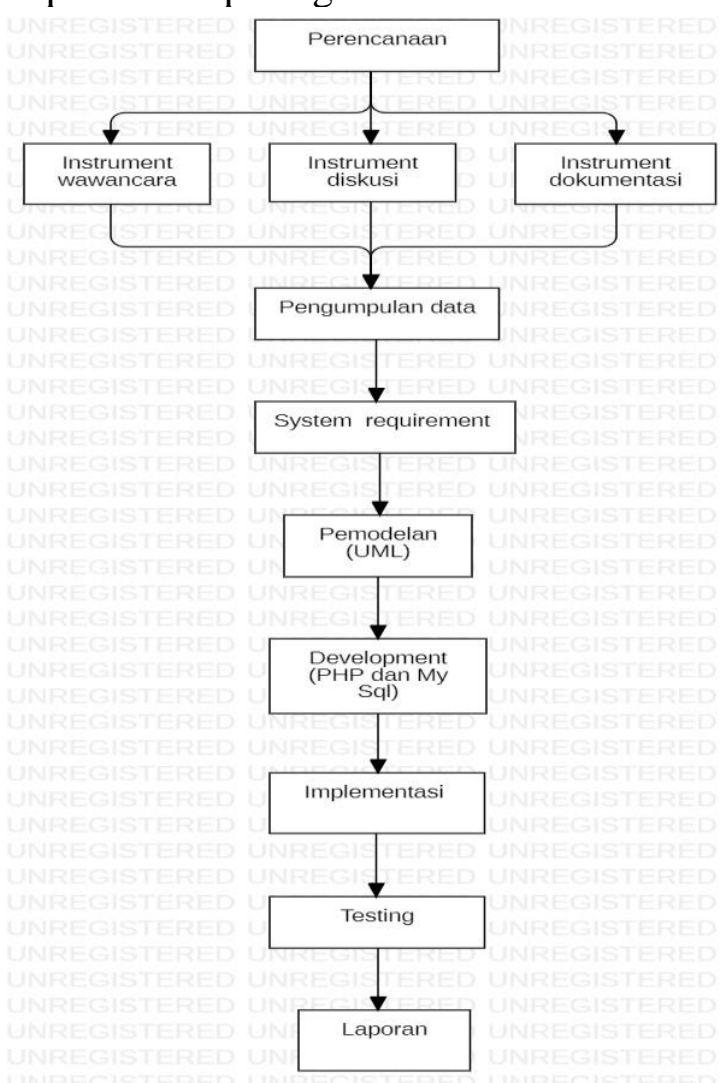

Gambar 1 : Tahapan Penelitian

Keterangan Gambar :

a. Perencanaan: pada tahap ini, peneliti melakukan penyusunan kisi - kisi penelitian yang didalamnya terdeskripsikan data atau informasi yang 
digali, sumber data, teknik pengambilan data serta pertanyaan yang akan diajukan kepada sumber data.

b. Penyusunan Instrumen: pada tahap ini, peneliti melakukan penyusunan instrumen penelitian berdasarkan kisi kisi yang telah disusun.

c. Pengumpulan Data: Pada tahap ini, peneliti melakukan pengumpulan data berdasarkan kisi - kisi yang telah dibuat dan dengan panduan instrumen yang telah disusun.

d. System requirement: Pada tahap ini, peneliti melakukan penyusunan business process improvement beradasarkan business process diagram yang berjalan pada objek penelitian sehingga dihasilkan sebuah rekomendasi proses bisnis baru yang diharapkan dapat meningkatkan efektivitas dan efisiensi dari proses bisnis sebelumnya.

e. Pemodelan: pada tahapan ini, peneliti melakukan pemodelan aplikasi menggunakan unified modeling language (UML). Pemodelan ini dibuat berdasarkan hasil analisis kebutuhan aplikasi.

f. Development: pada tahapan ini, peneliti melakukan analisis kebutuhan aplikasi berdasarkan hasil rekomendasi proses bisnis baru yang telah disusun pada tahap business process improvement. Hasil dari analisis kebutuhan aplikasi ini adalah sebuah fitur - fitur yang merupakan kebutuhan fungsional dari aplikasi yang akan dikembangkan.

g. Implementasi: pada tahapan ini, penelitian melakukan implementasi terhadap aplikasi yang disesuaikan permintaan user.

h. Testing: pada tahapan ini, peneliti melakukan black box testing terhadap 1 user yang mengujinya.

i. Laporan: pada tahapan ini, peneliti melakukan dokumentasi laporan yang berupa laporan analisis dan pemodelan.

\section{Hasil dan Pembahasan}

Berdasarkan penelitian terhadap perusahaan yang diteliti mendapatkan informasi prosedur sistem yang berjalan sebagai berikut :

a. Marketing melakukan penawaran barang kepda konsumen

b. Konsumen memesan barang yang diinginkan sesuai price list

c. Marketing membuat nota pemesanan dan melaporkan keadmin

d. Admin menerima laporan dari marketing dan memeriksa nota pemesanan jika ada maka admin membuat surat jalan.

e. Driver menerima surat jalan dari admin dan menyiapkan barang untuk proses pengiriman

f. Driver mengirim barang sesuai dengan alamat yang ada pada surat jalan.

g. Selesai

Flowchart sistem yang sedang berjalan dapat dilihat sebagai berikut :

a. Flowchart pemesanan dan pengiriman barang

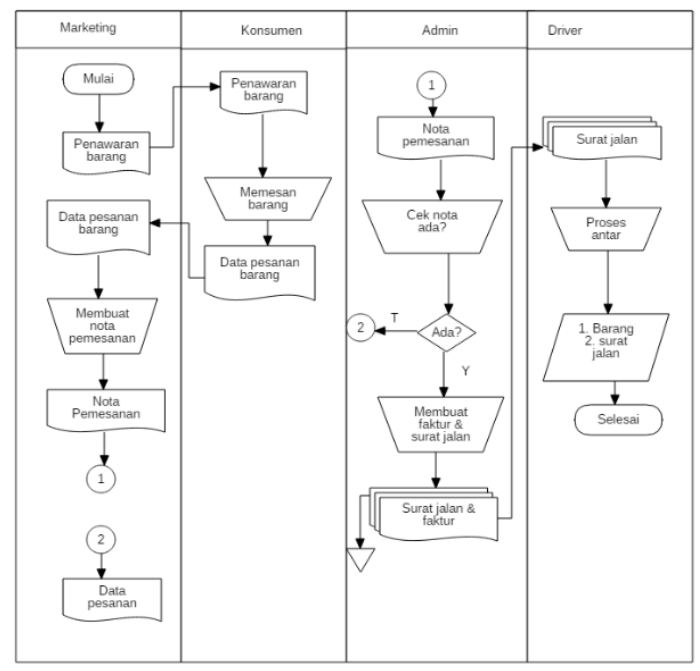

Gambar 2 : Flowchart Diagram pemesanan dan pengiriman barang sistem yang sedang berjalan

b. Flowchart Tracking Konsumen 


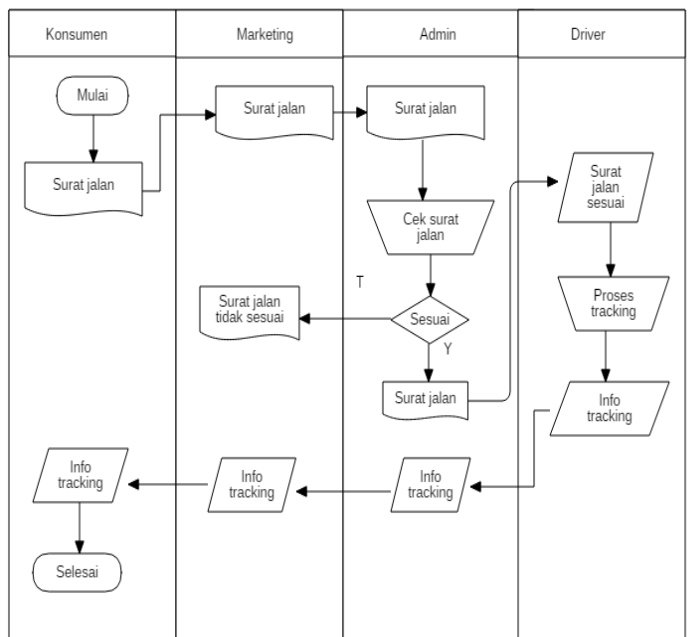

Gambar 3 : Flowchart Diagram Tracking konsumen sistem yang sedang berjalan

\section{Identifikasi Permasalahan}

Langkah awal dalam tahapan analisis adalah mengidentifikasi permasalahan yang tidak mampu ditangani oleh sistem, sehingga menyebabkan tidak tercapainya sasaran yang diinginkan. Dalam tahapan pengidentifikasian masalah penulis menggunakan metode analisis PIECES (Performance, Information, Economy, Control, Eficiency, Service). Berikut hasil analisis yang dilakukan penulis:

a. Performance (Analisis Kinerja)

Kinerja yang dimiliki CV Petroasia jaya utama dalam administrasi pemesanan, pengiriman dan pemantauan status pengiriman barang masih belum berjalan dengan baik, karena masih banyaknya proses yang belum terkomputerisasi dan menyebabkan banyak terjadi permasalahan-permasalahan pada pengelolaan data. Berikut adalah kinerja pada kegiatan pemantaun pengiriman barang:

2). Pengarsipan formulir masih belum maksimal dikarenakan masih menggunakan folder map yang dapat menyebabkan hilangnya surat dan membutuhkan banyak tempat.

3). Pencatatan pemesanan pengiriman barang dilakukan menggunakan buku dan agenda, sehingga dengan meningkatnya pemesanan produk atau barang sering timbul permasalahan yang terjadi seperti kesalahan pencatatan, dan rekapitulasi data pengiriman yang membutuhkan waktu cukup lama.

b. Information

Informasi dalam sistem administrasi dan pemantauan status pengiriman barang kurang baik dikarenakan perusahaan belum memiliki sistem web untuk usaha Jasa pesanan. Setiap perusahaan biasanya mempunyai web informasi untuk membantu calon konsumen mendapatkan apa yang mereka butuhkan. Sehingga dapat dengan mudah calon konsumen mendapatkan informasi tanpa harus datang langsung ke tempat/kantor CV Petroasia jaya utama.

c. Economic

Pada tahapan ekonomi CV Petroasia jaya utama memiliki peningkatan biaya dalam pengarsiapan data pengiriman masih menggunakan kertas yang mebutuhkan biaya cukup besar, untuk membeli kertas dan alat tulis.

d. Control

Data - data pemesanan dan pengirima barang pada CV Petroasia jaya utama penyimpanannya kurang teruji keamananya, karena penginputan data masih dari blangko/manual sehingga sering terjadi kerusakan dan akan membutuhkan waktu yang lama untuk memproses semuanya.

e. Efficiency

Pengolahan data pada CV Petroasia jaya utama memerlukan banyak waktu dan tenaga karena semua data dalam bentuk dokumen. Ketika akan melakukan penginputan data yang 
berhubungan, harus menginputkan data yang sama secara berulang.

f. Service

Pelayanan dalam memberikan informasi yang dibutuhkan pada CV Petroasia jaya utama tidak bisa cepat, karena sistem pengelolaan masih manual dan semua data yang diperlukan untuk rekapan data disajikan terpisah.

\section{Solusi Pemecahan Masalah}

Untuk menghadapi permasalahanpermasalahan yang terjadi CV. Petroasia Jaya Utama maka perlu adanya pemecahan masalah. Adapun alternatif pemecahan masalah yang terbaik pada saat ini adalah :

a. Membuat sistem yang dapat mempermudah tracking status pengiriman, pengelolaan data, serta penyimpanan data pengiriman barang, sehingga mudah untuk menemukan data saat membutuhkan.

b. Membuat sistem berbasis web yang dapat mempermudah proses pengelolaan data pemesanan barang, data pengiriman barang, data tracking status pengiriman pada CV Petroasia Jaya Utama.

c. Diperlukan software (perangkat lunak) yang mendukung untuk membuat sistem informasi berbasis web secara komputerisasi dengan menggunakan XAMPP yang dapat mempermudah proses pengelolaan data pemesanan,data pengiriman barang, data tracking barang yang mudah ditemukan saat dibutuhkan.

\section{Flowchart usulan pada aplikasi Tracking Delivery}

Flowchart diagram dibawah ini merupakan usulan alur proses tracking pengiriman barang pada CV Petroasia Jaya Utama

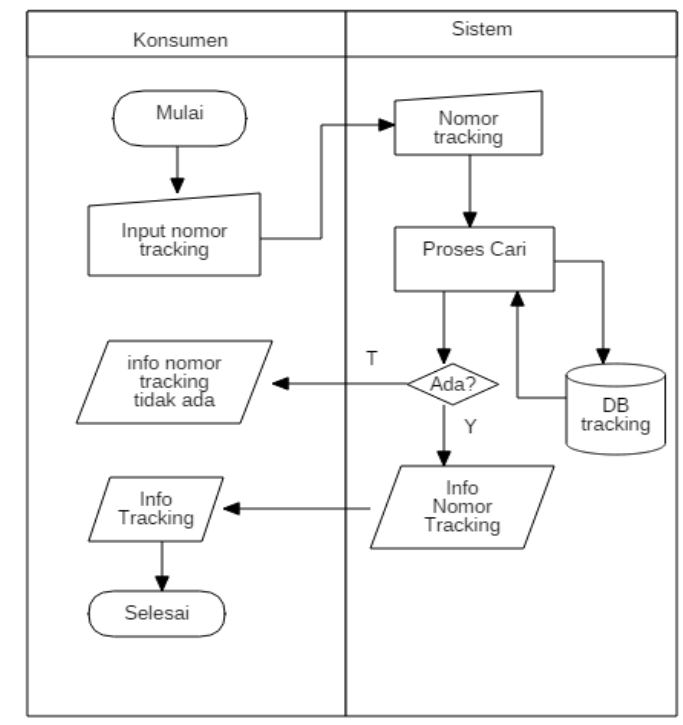

Gambar 4 : Flowchart usulan pada aplikasi Tracking Delivery

\section{Pemodelan System Usulan}

Berikut pemodelan system usulan menggunakan UML :

\section{Use Case Konsumen}

Dibawah ini adalah menggambarkan usecase dari aplikasi Tracking delivery. Pada usecase ini terdiri dari satu aktor yaitu konsumen.

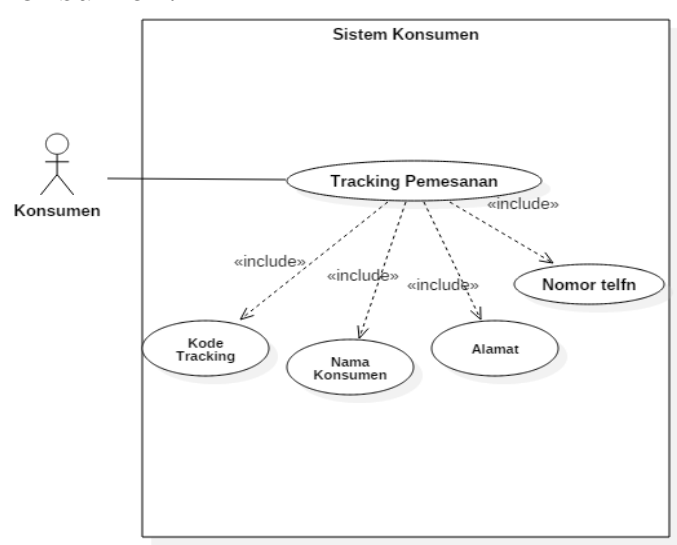

Gambar 5 : Use Case Konsumen

\section{Use Case Admin}

Dibawah ini adalah menggambarkan usecase dari aplikasi Tracking delivery. Pada usecase ini terdiri dari satu aktor yaitu Admin. 


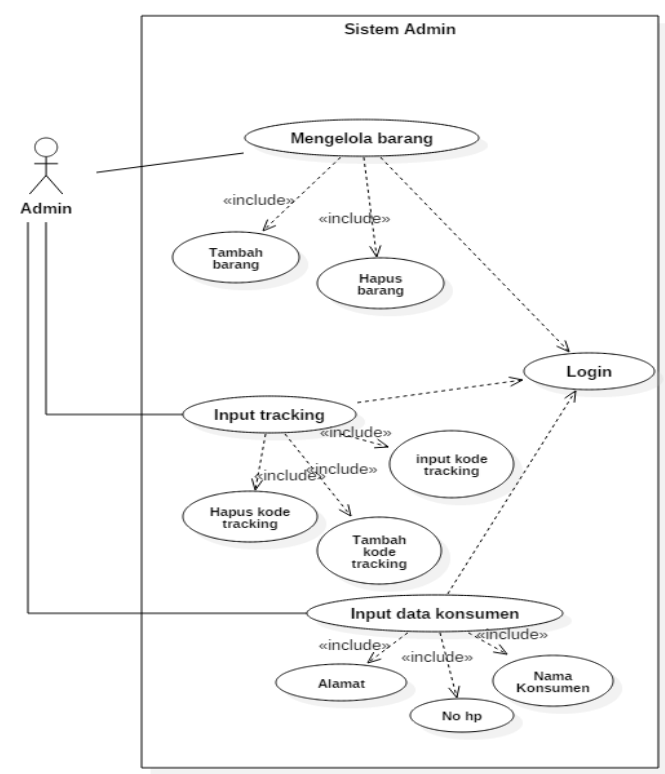

Gambar 6 : Use Case Admin

\section{Activity Diagram Pemesanan Barang}

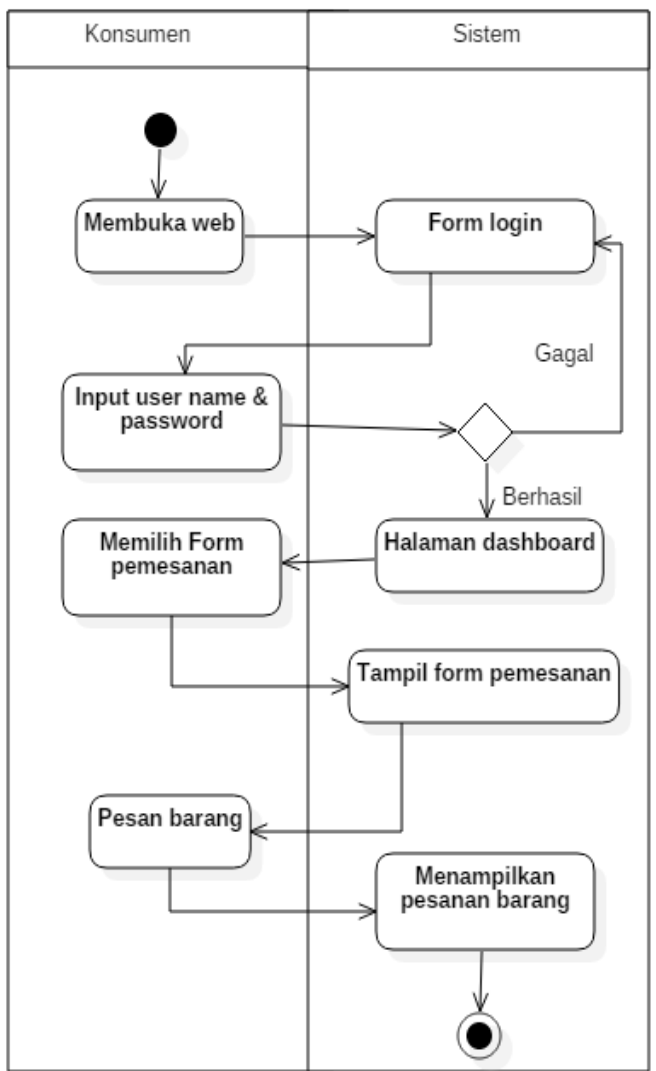

Gambar 7 : Activity Diagram Pemesanan Barang

\section{Activity Diagram Tracking}

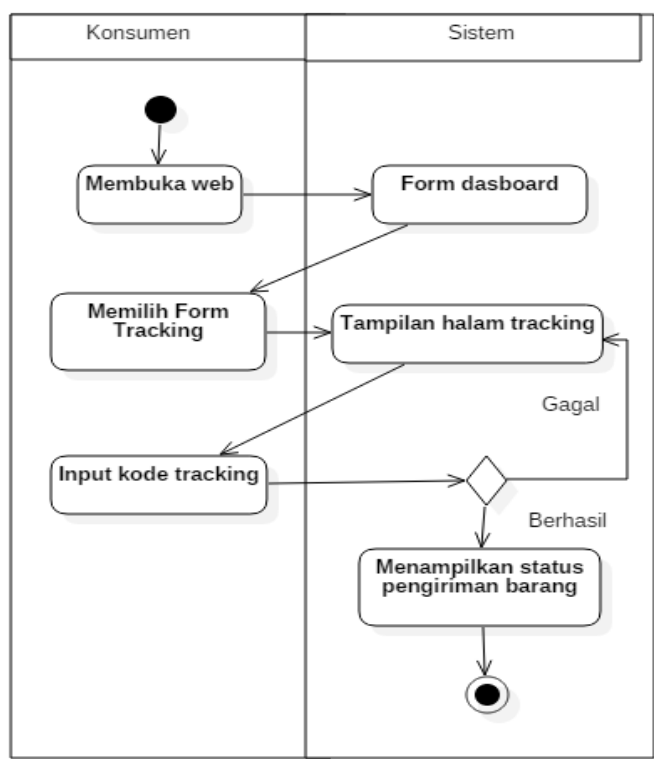

Gambar 8 : Activity Diagram Tracking

Class Diagram

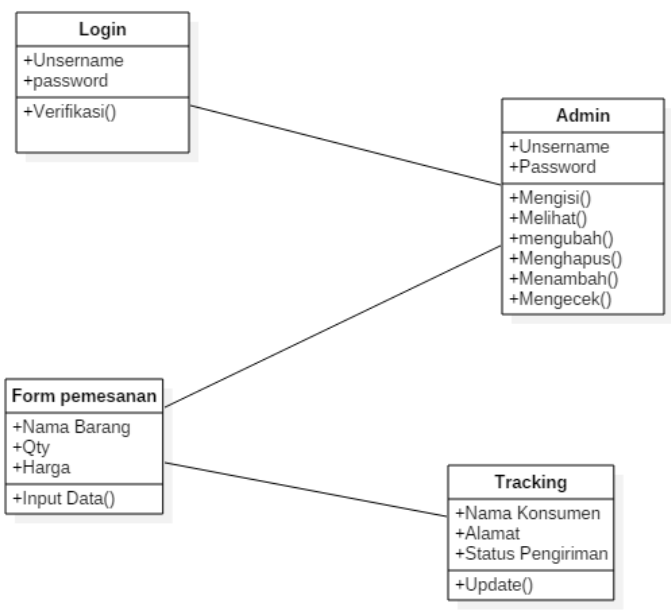

Gambar 9 : Class Diagram

\section{Tampilan Hasil}

Berikut ini dijelaskan tentang Interface (tampilan) hasil dari Desain Sistem Tracking Delivery berbasis Web dapat dilihat sebagai berikut :

\section{Form Tampilan Login}

Form tampilan $\log$ in berfungsi untuk menerima Input dari user yang mempunyai akses ke dalam aplikasi, dengan cara memasukkan email dan password, apabila valid dan sesuai akan 
diteruskan ke menu utama berdasarkan hak akses.

Berikut adalah interface form Login :

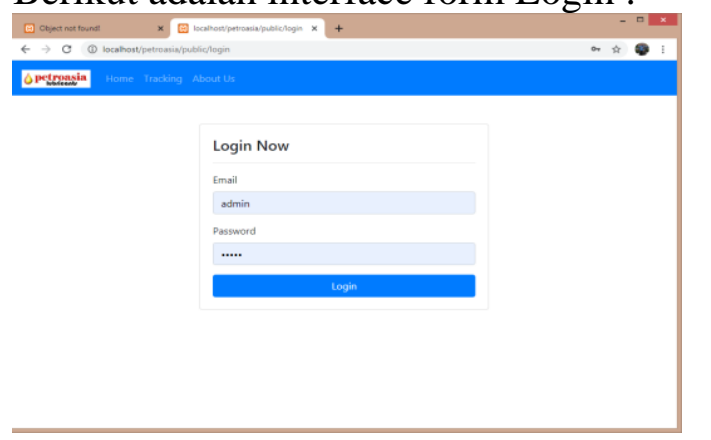

Gambar 9 : Form Tampilan Login

\section{Tampilan Halaman Utama Akses Administrator}

Tampilan ini merupakan tampilan awal pada hak akses Administrator, yang didalamnya terdapat menu-menu seperti pemesanan barang, konsumen, oreder, Pengiriman. Dapat dilihat sebagai berikut :

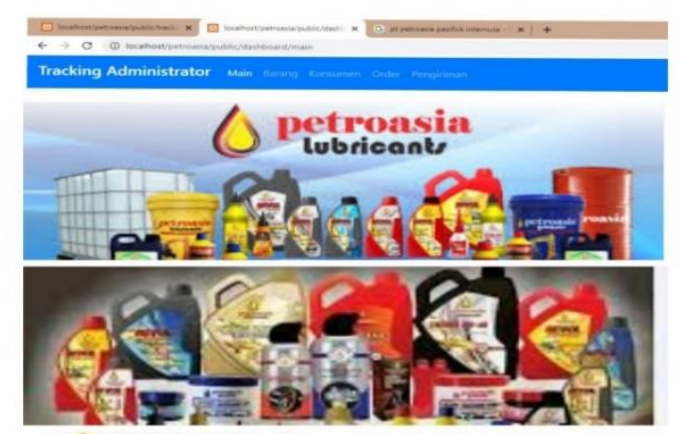

Gambar 10 : Tampilan Halaman Utama Akses Administrator

\section{Tampilan Form Konsumen}

Pada halaman ini digunakan untuk mengelola data-data Konsumen, baik untuk menambahkan menghapus.

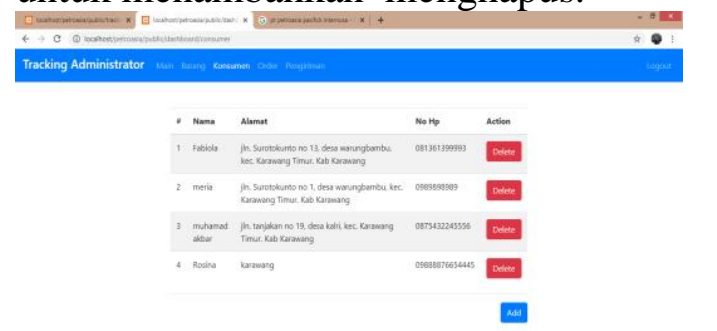

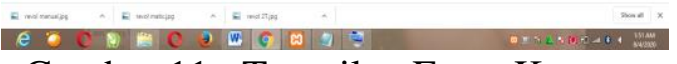

Gambar 11 : Tampilan Form Konsumen Tampilan Form Order atau Pemesanan Barang
}

Pada halaman ini digunakan untuk memesan barang yang diinginkan oleh konsumen, didalamnya terdapat menumenu seperti nama konsumen serta menu menambahkan dan menghapus pemesanan.

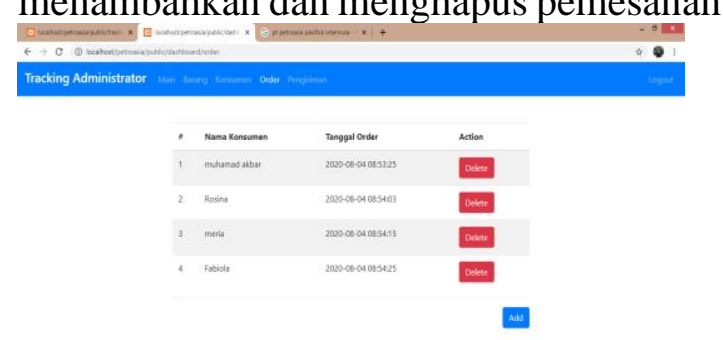

Gambar 12 : Tampilan Form Order atau Pemesanan Barang

\section{Tampilan From Pengiriman}

Form tampilan ini berfungsi untuk melihat Kode tracking, Status pengiriman serta menu update status pengiriman.

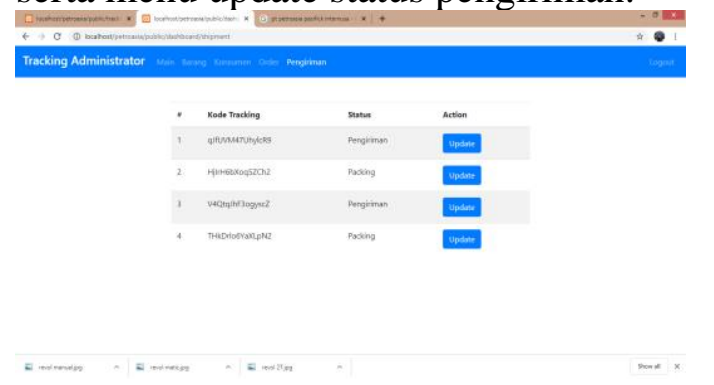

Gambar 13 : Tampilan From Pengiriman Tampilan From Konsumen Melihat Tracking Pengiriman

Form tampilan ini berfungsi untuk konsumen melihat satus pengiriman barang.

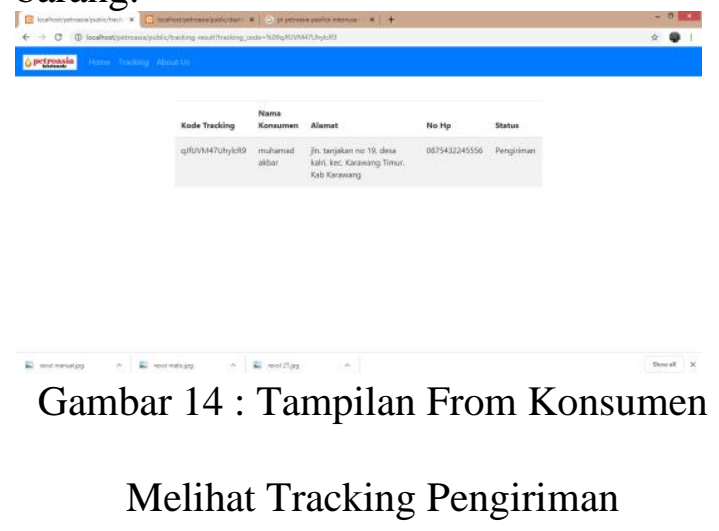

Jurnal Interkom: Jurnal Publikasi Ilmiah Bidang Teknologi Informasi dan Komunikasi

Volume 15 Nomor 03 Bulan Oktober - Tahun 2020 


\section{Pengujian}

Tabel 1. Pengujian Blackbox Testing Halaman Login

\begin{tabular}{|c|c|c|c|c|c|}
\hline No & $\begin{array}{l}\text { Skenario } \\
\text { Pengujian }\end{array}$ & Tes Case & \begin{tabular}{c|} 
Hasil \\
yang \\
diharapk \\
an
\end{tabular} & $\begin{array}{c}\text { Hasil } \\
\text { pengujian }\end{array}$ & $\begin{array}{c}\text { Kesimpul } \\
\text { an }\end{array}$ \\
\hline 1 & $\begin{array}{l}\text { User } \\
\text { name dan } \\
\text { pass darord } \\
\text { tidak disis } \\
\text { kemudian } \\
\text { klik } \\
\text { tombol } \\
\text { login }\end{array}$ & $\begin{array}{l}\text { User } \\
\text { name } \\
\text { (kosong) }\end{array}$ & 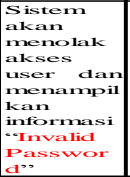 & $\begin{array}{c}\text { Sesuai } \\
\text { harapan }\end{array}$ & valid \\
\hline 2 & $\begin{array}{l}\text { Mengetilk } \\
\text { User dan } \\
\text { name dassword } \\
\text { passwordiis } \\
\text { tidak dik } \\
\text { kemudian } \\
\text { kem } \\
\text { tombol } \\
\text { login }\end{array}$ & $\begin{array}{l}\text { User } \\
\text { name } \\
\text { admin } \\
\text { password } \\
\text { passwong) } \\
\text { (kossong) }\end{array}$ & \begin{tabular}{|l|} 
Sistem \\
akan \\
menolak \\
akses dan \\
user dan \\
menampil \\
lkan \\
informasi \\
"Invalid \\
Passwor \\
d"roswor
\end{tabular} & $\begin{array}{c}\text { Sesuai } \\
\text { harapan }\end{array}$ & valid \\
\hline 3 & $\begin{array}{l}\text { Mengetik } \\
\text { User } \\
\text { name dan } \\
\text { password } \\
\text { Kemudian } \\
\text { klik } \\
\text { tombol } \\
\text { login }\end{array}$ & $\begin{array}{l}\text { User } \\
\text { name } \\
\text { admin } \\
\text { (benar) } \\
\\
\text { password } \\
\text { (salah) } \\
\text { (sala }\end{array}$ & 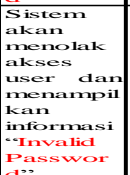 & $\begin{array}{c}\text { Sesuai } \\
\text { harapan }\end{array}$ & valid \\
\hline 4 & $\begin{array}{l}\text { Mengetik } \\
\text { User } \\
\text { name dan } \\
\text { password } \\
\text { kemudian } \\
\text { klik } \\
\text { tombol } \\
\text { login }\end{array}$ & $\begin{array}{l}\text { User } \\
\text { name } \\
\text { admi } \\
\text { (salah) } \\
\\
\text { password } \\
\text { ' admin } \\
\text { (benar) }\end{array}$ & 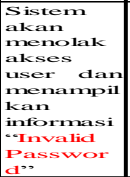 & $\begin{array}{c}\text { Sesuai } \\
\text { harapan }\end{array}$ & valid \\
\hline 5 & $\begin{array}{l}\text { Mengetik } \\
\text { User } \\
\text { name dan } \\
\text { password } \\
\text { kemudian } \\
\text { klik } \\
\text { tombol } \\
\text { login }\end{array}$ & $\begin{array}{l}\text { User } \\
\text { name } \\
\text { admin } \\
\text { (benar) } \\
\text { password } \\
\text { padmin } \\
\text { (benar) }\end{array}$ & \begin{tabular}{|l|} 
Sistem \\
menerima \\
akses \\
akgin dan \\
kemudian \\
langsumg \\
menampil \\
Kan menu \\
utama \\
\end{tabular} & $\begin{array}{c}\text { Sesuai } \\
\text { harapan }\end{array}$ & valid \\
\hline
\end{tabular}

Tabel 2. Pengujian Blackbox Testing Halaman Konsumen

\begin{tabular}{|c|l|l|l|l|l|}
\hline No & $\begin{array}{l}\text { Skenario } \\
\text { Pengujian }\end{array}$ & Tes Case & $\begin{array}{c}\text { Hasil } \\
\text { yang } \\
\text { diharapk } \\
\text { an }\end{array}$ & $\begin{array}{c}\text { Hasil } \\
\text { pengujian }\end{array}$ & $\begin{array}{c}\text { Kesimpul } \\
\text { an }\end{array}$ \\
\hline 1 & $\begin{array}{l}\text { Alamat } \\
\text { atau } \\
\text { nomor hp } \\
\text { tidak diisi } \\
\text { kemudian } \\
\text { klik } \\
\text { tombol } \\
\text { add }\end{array}$ & $\begin{array}{l}\text { Alamat } \\
\text { hp } \\
\text { kosong } \\
\text { kanan } \\
\text { kenolak }\end{array}$ & $\begin{array}{l}\text { nostuk } \\
\text { penyimpa } \\
\text { nan data } \\
\text { pelajaran } \\
\text { dan }\end{array}$ & $\begin{array}{c}\text { Sesuai } \\
\text { harapan }\end{array}$ & valid \\
\hline 2 & $\begin{array}{l}\text { Alamat } \\
\text { atau } \\
\text { nomor hp } \\
\text { tidak diisi } \\
\text { kemudian } \\
\text { klik } \\
\text { tombol } \\
\text { add }\end{array}$ & $\begin{array}{l}\text { Deskripsi } \\
\text { diisi }\end{array}$ & $\begin{array}{l}\text { Sistem } \\
\text { menerima } \\
\text { untuk } \\
\text { penyimpa } \\
\text { nan data } \\
\text { pelajaran }\end{array}$ & Sesuai \\
harapan & valid \\
\hline
\end{tabular}

Tabel 3. Pengujian Blackbox Testing Order atau Pemesanan Barang

\begin{tabular}{|c|l|l|l|l|l|}
\hline No & $\begin{array}{l}\text { Skenario } \\
\text { Pengujian }\end{array}$ & Tes Case & $\begin{array}{c}\text { Hasil } \\
\text { yang } \\
\text { diharapk } \\
\text { an }\end{array}$ & $\begin{array}{c}\text { Hasil } \\
\text { pengujian }\end{array}$ & $\begin{array}{c}\text { Kesimpul } \\
\text { an }\end{array}$ \\
\hline 1 & $\begin{array}{l}\text { Salah } \\
\text { satu data } \\
\text { tidak diisi }\end{array}$ & $\begin{array}{l}\text { Salah } \\
\text { satu isian } \\
\text { kosong } \\
\text { akan } \\
\text { menolak } \\
\text { dan } \\
\text { menampil } \\
\text { kan } \\
\text { informasi } \\
\text { kesalahan }\end{array}$ & $\begin{array}{c}\text { Sesuai } \\
\text { harapan }\end{array}$ & Valid \\
\hline 2 & $\begin{array}{l}\text { Semua } \\
\text { data diisi }\end{array}$ & $\begin{array}{l}\text { Tidak } \\
\text { ada data } \\
\text { yang } \\
\text { kosong }\end{array}$ & $\begin{array}{l}\text { Sistem } \\
\text { menerima } \\
\text { penyimpa } \\
\text { nan data. }\end{array}$ & Sesuai \\
harapan & Valid \\
\hline
\end{tabular}

\section{Penutup}

\section{a. Kesimpulan}

Berdasarkan analisis dan pembahasan yang telah diuraikan pada bab-bab sebelumnya dan hasil rancangan serta implementasi sistem Tracking delivery berbasis web, maka dapat diambil beberapa kesimpulan sebagai berikut:

1). Pada sistem tracking delivery ini, permasalahan mengenai pemesanan barang, pengiriman dan pemantauan status pengiriman barang masih bersifat konvensional, yaitu dicatat menggunakan media kertas, sehingga dengan adanya aplikasi berbasis web diharapkan mengurangi beban kerja Admin.

2). Sistem Tracking ini mempunyai fasilitas-fasilitas yang dapat membantu konsumen dalam memesan barang dan melihat status pengiriman barang secara cepat.

3). Sistem Tracking ini mempunyai fasilitas-fasilitas 
yang dapat membantu dalam penginputan maupun penghapusan data secara cepat, serta memudahkan dalam pembuatan laporan.

4). Laporan yang dihasilkan dari sistem tracking status pengiriman barang tersebut akan membantu admin dalam pembuatan laporan pengiriman

\section{b. Saran}

Terdapat beberapa hal yang belum digali lebih mendalam dan menyeluruh di dalam perancangan ini, sehingga beberapa diantaranya masih dapat dikembangkan dan diperbaiki, antara lain:

1). Sebelum menerapkan sistem Tracking berbasis web ini, CV Petroasia Jaya Utama perlu melakukan pelatihan atau pembelajaran untuk mengoperasikan sistem tersebut sehingga tidak terjadi kesalahan dalam pengoperasiannya.

2). Penulis berharap dengan adanya sistem tracking delivery berbasis web ini, CV Petroasia Jaya Utama dapat secara up to date dan relevan.

3). Sistem harus dikembangkan lebih lanjut dengan meminimalisir terjadinya kesalahan, yaitu dengan memaksimalkan sintaks dan tampilan sebagai peringatan terjadinya kesalahan pada saat penginputan.

\section{Daftar Pustaka}

[1] Beisse, F. (2013). A Guide to Computer User Support for HelpDesk \& Support Specialist, edisi ke-5. In C. J. Gaol, Sistem informasi manajemen pemahaman dan aplikasi. Jakarta.

[2] Bolung, M. a. (2017). ANALISIS
PENGGUNAAN METODOLOGI PENGEMBANGAN PERANGKAT LUNAK. Jurnal ELTIKOM.

[3] D.S. Budhi, (2017). ANALISIS PENGGUNAAN METODOLOGI PENGEMBANGAN PERANGKAT LUNAK. Jurnal ELTIKOM.

[4] Fabbly. (2019). Business Proces Improvement, doi:10.1201/B122707.

[5] H. J. Harrington, (1991). Business Proces Change, Business Proces Change, doi:10.1016/B978-0-12374152-3.X5027-7.

[6] Hiles. (2007). The Definiti Handbook of Business Continuty management . England: John wiley \& Sons.

[7] M. Stefani. Yulianto J.P, Sri. Setyawan, Martin. 2012. "Sistem Informasi Tracking Pengiriman Barang pada Online Shopping Berbasis SMS Gateway pada PT Karunia Inti Jaya Agrisarana". Salatiga : Universitas Kristen Satya Wacana.

[8] Mustakini, Jogiyanto Hartono. 2009. "Sistem Informasi Teknologi". Yogyakarta : Andi Offset.

[9] Mustika, "Aplikasi Tracking Paket Barang Ekspedisi Pada Pt . Bahari Eka Nusantara Palembang," Teknol. Dan Inform., 2012.

[10] M. Nazir, (2011). METODE PENELITIAN (EDISI 7). JAKARTA: Ghalia Indonesia.

[11] Nugroho. (2010). BUKU AJAR OBSTETRI. Yogyakarta: Nuha Medika.

[12] Nugroho. 2010. "Rekayasa Perangkat Lunak Menggunakan UML". Yogyakarta : Andi Offset.

[13] S. a. Dharwiyanti, (2003). PENGANTAR UNIFIED MODELLING LANGUAGE (UML).

[14] S. Lila, (2018). Research Methods Information Technology. 
[15] S. Arikunto (2006). Prosedur Penelitian : Suatu Pendekatan Praktik (edisi revisi VI). Jakarta: PT. Rineka Cipta.

[16] W. Abdillah, (2018). METODE PENELITIAN TERPADU SISTEM INFORMASI. YOGYAKARTA: Andi.

[17] Y. A. Nasution, H. Dhika, and S. Rezeki, "Sistem Tracking Online Pengiriman Barang dan Dokumen di PT SCAM," J. Ris. dan Apl. Mhs. Inform., 2020, doi: 10.30998/jrami.v1i03.445. 